\title{
Impact of Krishibhagya Yojana on Socio-Economic Dimensions of Farmers in North Eastern Karnataka, India
}

\author{
M. Thimmesha, Jagrati B. Deshmanya and K. Suresh* \\ Department of Agricultural Economics, College of Agriculture, Raichur, 584104, India \\ *Corresponding author
}

Keywords

farm pond, impact, krishibhagya, socioeconomic dimension.

\section{Article Info}

Accepted:

05 January 2020

Available Online:

10 February 2020

\section{A B S T R A C T}

The present paper explores the impact of Krishibhagya Yojana on socioeconomic status of farmers. For the study, multi stage random sampling technique was employed to select the farmers from Bidar, Yadgir and Kalaburagi district of North Eastern Karnataka. Both primary and secondary data were collected for the study. The study reveals that a positive impact after implementation of KBY as compared with the before implementation of KBY. In case of farm buildings, the farm house, cattle shed, poultry shed were increased significantly about 90, 60 and 100 per cent, respectively as compared to before implementation of KBY. The migration of farmers decreased after the implementation of KBY to the extent of 38.89 per cent. Whereas, the duration of migration is also get reduced after the implementation of the scheme to 31.58 per cent as compared to before the implementation of KBY. It was also found that there was an increased in the family expenditures after implementation of KBY such as food expenditure, clothing expenditure, medical expenditure, entertainment expenditures and children's education as compared with the before implementation of KBY.

\section{Introduction}

Indian agriculture has witnessed a wide variation in growth performance during the last six decades after independence. The variability is particularly pronounced due to the subsistence nature of farming in India and heavy depends on monsoon and other physical and chemical factors of soil. In India,
60 per cent of total cultivated area is rainfed, which means that crop production in these areas is dependent on rainfall, having no facility for protective or lifesaving irrigation.

Karnataka is important agricultural based state, having 70 per cent of cultivable land under dry land condition. The dry land area contributes 55 per cent of food grains and 75 
per cent of oilseed production to the overall agricultural production of the state.

Karnataka has 10 agro-climatic zones, out of which five are dry zones, farmers in dry land areas are small and marginal farmers facing more uncertain climatic situation.

By considering problems in and convert subsistence agriculture in to sustainable agriculture in dry zones.

Government of Karnataka implemented a new scheme called "Krishi Bhagya Yojana". to unlock the potential of rainfed agriculture, to achieve revolutionary change in Karnataka's farm sector on September 2014.

Under this scheme, government is committed to transform agricultural sector by increasing farm productivity through infusion of new technology and equipments, sustainable agricultural practices and better water management and irrigation facilities in the state.

In 2016, the Government of Karnataka extended the scheme to all the zones of Karnataka.

The prime objectives of the scheme is to convert subsistence farming into sustainable farming, harvest and conserve rain water, provide protective irrigation facilities, improve soil fertility and productivity of dry land agriculture, promote horticulture under both opened conditions in dry land regions and finally increase the socio-economic condition of dry land farmers.

Major benefits of farm ponds are to meet the water demand for domestic animal and recreational use, lifesaving irrigation to crops and plantation, augment ground water recharge, improve in soil moisture, reduction in soil erosion, flood control and for spraying chemicals (Adhikari et al., 2009).

Hence, the present study has undertaken with the following objective:

1. To measure the socio-economic dimensions among beneficiaries and non-beneficiaries of Krishibhagya Yojana.

2. To study the impact of Krishibhagya scheme on migration of farmers.

3. To assess the change in family living expenditure due to implementation of farm pond scheme.

\section{Materials and Methods}

For the study, multi stage random sampling technique was employed to select the farmers from Bidar, Yadgir and Kalaburagi district for which 150 sample farmers were selected, out of this, 75 farmers are beneficiaries of KBY and 75 farmers are non-beneficiaries of KBY.

Both primary and secondary data were collected for the study. The secondary data pertains to the list of the beneficiaries of KBY from RSK's of different taluks in the study area.

The primary data related to the agriculture year 2017-18 was elicited using pre-tested structured schedules.

Tabular analysis was employed including percentages and averages for both the sample farmer's group to facilitate better comparison.

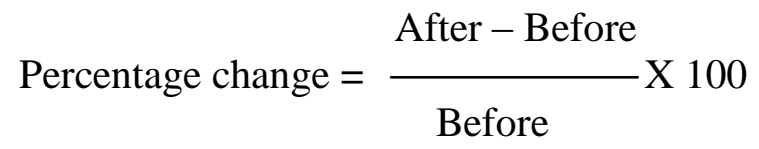




\section{Results and Discussion}

\section{Impact of Krishibhagya Yojana on socio- economic dimensions of farmer beneficiaries}

It is evidenced from the table 1 that, the percentage change in possession of livestock assets such as local cows, cross breed cows, local buffaloes, bullock pairs, poultry layers, Sheep and goat are 29.85, 33.30, 42.85, 25, $22.22,68.75$ and 66.66 per cent, respectively. The local buffalos, bullock pairs and poultry birds increased significantly as compared to before KBY.

The change in asset possession are presented in the table 2 reveals a positive impact after implementation of KBY as compared with the before implementation of KBY. In case of farm buildings, the farm house, cattle shed, poultry shed were increased significantly about 90, 60 and 100 per cent, respectively as compared to before implementation of KBY. In case of farm assets, the possession of assets like pumpset, tractor, seed drill and sprayers has increased significantly about 48, 40, 40 and 28.57 per cent, respectively compared to before implementation of KBY. The household assets like the number of scooter, television and mobile used has increased about $114,41.53$ and 40.25 per cent, respectively as compared to before KBY. In case of financial assets, the saving deposits and gold assets were increased by 70.59 and 48.13 per cent, respectively.

In overall the farm buildings, farm assets, household assets and financial assets after the implementation of KBY increased about $82.35,31.42,42.25$ and 54.50 per cent, respectively after the implementation of KBY. The farm house, pump set, sprayers, two wheelers were increased significantly at 5 per cent level.

Table.1 Impact of KBY on livestock asset possession among beneficiaries

\begin{tabular}{|c|c|c|c|c|}
\hline \multirow[t]{2}{*}{ SI. No. } & \multirow[t]{2}{*}{ Animals } & Before $(2013-14)(n=75)$ & After (2014-15) $(n=75)$ & \multirow[t]{2}{*}{ \% Change } \\
\hline & & Average No. & Average No. & \\
\hline 1 & Local cows & 0.67 & 0.87 & 29.85 \\
\hline 2 & Cross breed cows & 0.06 & 0.08 & 33.30 \\
\hline 3 & Local buffalos & 0.70 & 1.00 & $42.85^{*}$ \\
\hline 4 & Cross breed buffalos & 0.04 & 0.05 & 25.00 \\
\hline 5 & Bullock pairs & 0.18 & 0.22 & $22.22 *$ \\
\hline 6 & Poultry birds & 0.16 & 0.27 & $68.75^{*}$ \\
\hline 7 & Sheep & 0.12 & 0.20 & 66.66 \\
\hline 8 & Goat & 0.10 & 0.13 & 30.00 \\
\hline & Total & 2.03 & 2.82 & 38.91 \\
\hline
\end{tabular}

Note: * indicates significant at $5 \%$ level 
Table.2 Impact of KBY on asset possession among beneficiaries

\begin{tabular}{|c|c|c|c|c|}
\hline \multirow[t]{2}{*}{$\begin{array}{l}\text { SI. } \\
\text { No. }\end{array}$} & \multirow[t]{2}{*}{ Particulars } & $\begin{array}{c}\text { Before }(2013-14) \\
(n=75)\end{array}$ & $\begin{array}{c}\text { After }(2014-15) \\
(n=75)\end{array}$ & \multirow[t]{2}{*}{$\%$ change } \\
\hline & & Average no. & Average no. & \\
\hline \multirow[t]{5}{*}{ I } & \multicolumn{4}{|l|}{ Farm buildings } \\
\hline & 1. Farm house & 0.10 & 0.19 & $90.00 *$ \\
\hline & 2. Cattle shed & 0.05 & 0.08 & 60.00 \\
\hline & 3. Poultry shed & 0.02 & 0.04 & 100.00 \\
\hline & Total & 0.17 & 0.31 & 82.35 \\
\hline \multirow[t]{10}{*}{ II } & \multicolumn{4}{|l|}{ Farm assets } \\
\hline & 1. Tractor & 0.05 & 0.07 & 40.00 \\
\hline & 2. Power tiller & 0.26 & 0.33 & 33.33 \\
\hline & 3. Bullock cart & 0.16 & 0.18 & 12.50 \\
\hline & 4. Pump set & 0.25 & 0.41 & $48.00 *$ \\
\hline & 5. Seed drill & 0.05 & 0.07 & 40.00 \\
\hline & 6. Sprayers & 0.14 & 0.17 & $28.57 *$ \\
\hline & 7. Cultivator & 0.12 & 0.14 & 16.66 \\
\hline & 8. Rotovator & 0.03 & 0.03 & 00.00 \\
\hline & Total & 1.4 & 1.84 & 31.42 \\
\hline \multirow[t]{8}{*}{ III } & \multicolumn{4}{|l|}{ Household assets } \\
\hline & 1. Bicycle & 0.16 & 0.13 & -18.75 \\
\hline & 2. Two wheeler & 0.42 & 0.88 & $114.28 *$ \\
\hline & 3. Radio & 0.33 & 0.28 & -15.15 \\
\hline & 4. Television & 0.65 & 0.92 & $41.53 *$ \\
\hline & 5. Refrigerator & 0.06 & 0.09 & 50.00 \\
\hline & 6. Mobile & 0.77 & 1.08 & $40.25^{*}$ \\
\hline & Total & 2.39 & 3.40 & 42.25 \\
\hline \multirow[t]{7}{*}{ IV } & \multicolumn{4}{|l|}{ Financial assets } \\
\hline & 1. Saving deposit & $1,10,000$ & $1,87,655.00$ & 70.59 \\
\hline & 2. Fixed deposit & - & - & \\
\hline & 3. Bonds & - & - & \\
\hline & 4. Insurance & 8350 & 10740 & 28.62 \\
\hline & 5. Gold & 75,315 & $1,11,571$ & 48.13 \\
\hline & Total & 193665 & $2,99,226$ & 54.50 \\
\hline
\end{tabular}


The migration details of the beneficiaries before and after implementation of KBY was worked out and presented in table 3. The migration of farmers decreased after the implementation of KBY to the extent of 38.89 per cent. Whereas, the duration of migration is also get reduced after the implementation of the scheme to 31.58 per cent as compared to before the implementation of KBY. It also observed that there was a hike in wages $(22.22 \%)$ for farm operations after the implementation of scheme due to demand of labourers.

Table.3 Impact of Krishibhagya scheme on change in migration among the beneficiaries

\begin{tabular}{|c|l|c|c|c|}
\hline Sl. No. & \multicolumn{1}{|c|}{ Particulars } & $\begin{array}{c}\text { Before (2013-14) } \\
\mathbf{n = 7 5}\end{array}$ & $\begin{array}{c}\text { After (2014-15) } \\
\mathbf{n = 7 5}\end{array}$ & \% Change \\
\hline 1 & No. of persons & 18 & 11 & -38.89 \\
\hline 2 & Duration (Days/ year) & 95 & 65 & -31.58 \\
\hline 3 & Nature of migration & & & \\
\hline & a. Single & 8.00 & 5.00 & -37.58 \\
\hline & b. Family & 10.00 & 6.00 & -40.00 \\
\hline & c. Wages(in ) & 450.0 & 550.00 & 22.22 \\
\hline
\end{tabular}

Table.4 Impact of Krishibhagya scheme on family expenditure of beneficiaries (Rs./Year)

\begin{tabular}{|c|l|c|c|c|}
\hline Sl. No. & \multicolumn{1}{|c|}{ Particulars } & $\begin{array}{c}\text { Before (2013-14) } \\
\mathbf{n = 7 5}\end{array}$ & $\begin{array}{c}\text { After (2014-15) } \\
\mathbf{n = 7 5}\end{array}$ & \% Change \\
\hline & & 41052.00 & 45612.00 & 11.10 \\
\hline $\mathbf{1}$ & Food & 1631.00 & 2030.00 & 24.44 \\
\hline 3 & Cloth & 406.66 & 500.00 & 12.22 \\
\hline 4 & Medical & 3002.4 & 3927.26 & 30.80 \\
\hline 5 & Entertainment & 1806.66 & 2216.44 & 22.05 \\
\hline 6 & Social and religious function & 248.00 & 368.33 & 48.37 \\
\hline 7 & Children education & 1770.66 & 2928.00 & 65.36 \\
\hline 8 & Land improvement & 51967.00 & 57581.00 & 10.00 \\
\hline
\end{tabular}

The changes in the family expenditure among the beneficiaries are presented in the table 4 . It indicates that there was an increased in the family expenditures after implementation of KBY such as food expenditure, clothing expenditure, medical expenditure, 
entertainment expenditures and children's education as compared with the before implementation of KBY.

The percentage change after the implementation of KBY on food expenditure per month, clothing expenditure per month, expenditure on children education was 11.10 , 24.44 and 48.37 per cent, respectively. Similar results were found in study conducted by Kumar and Joshi (2003) and Vitthal (2017).

The major objectives of the Krishibhyagya Yojana i.e construction of farm ponds in farmers field is to convert subsistence farming into sustainable farming, harvest and conserve rain water, provide protective irrigation facilities, improve soil fertility and productivity of dry land agriculture, promote horticulture under both opened conditions in dry land regions and to increase the socioeconomic condition of dry land farmers.

After implementation of the scheme there was significant change in asset possession of the farmers, reduction in migration and increased family expenditure on food, cloth etc.

Therefore, the farmers should be motivated to construct farm ponds in their field through extension programmes for sustainable agriculture development and also for socioeconomic development of farmers.

\section{References}

Adhikari, R. N., Mishra, P.P. and Muralidhar, W., (2009),Dugout farm pond- potential source of water harvesting in deep black soils in Deccan plateau region. Proc. Nation. Workshop cum brain storming, Central Res .Inst. for Dryland Agric., Hyderabad, pp: 100-108.

Kumar, Praduman and Joshi P. K. (2013) Household consumption pattern and nutritional security among poor rural households: Impact of MGNREGA. Agric. Econ. Res. Rev., 26(1): 73-82.

Vitthal, Dipak Supe. (2017) Impact of farm pond on its beneficiaries in Marathwada region. M.Sc. (Agri.) Thesis, Vasantrao Naik Marathwada Krishi Vidyapeeth Parbhani (India).

\section{How to cite this article:}

Thimmesha. M, Jagrati B. Deshmanya and Suresh. K. 2020. Impact of Krishibhagya Yojana on Socio-Economic Dimensions of Farmers in North Eastern Karnataka, India. Int.J.Curr.Microbiol.App.Sci. 9(02): 381-386. doi: https://doi.org/10.20546/ijcmas.2020.902.047 